Archive for

Organic Chemistry

Arkivoc 2020, part vi, 139-154

\title{
Synthesis of novel bisphosphorylimides based on Staudinger reaction
}

\author{
Lais Weber ${ }^{a}$, Michael Weinert ${ }^{b}$, Daniela Goedderz $^{a}$, Olaf Fuhr ${ }^{c}$, and Manfred Döring ${ }^{a}$ \\ ${ }^{a}$ Fraunhofer Institute for Structural Durability and System Reliability LBF, 64289 Darmstadt, Germany \\ ${ }^{b}$ Fraunhofer Institute for Chemical Technology ICT, 76327 Pfinztal, Germany \\ 'Institute of Nanotechnology (INT) and Karlsruhe Nano Micro Facility (KNMF), Karlsruhe Institute of Technology, \\ 76344 Eggenstein-Leopoldshafen, Germany \\ Email: manfred.doering@lbf.fraunhofer.de
}

Received 01-08-2020

Accepted 04-23-2020

Published on line $05-04-2020$

\section{Abstract}

A series of bisphosphorylimides based on the reaction sequence of Atherton-Todd and Staudinger reaction were synthesized. These bisphosphorylimides containing phosphorus in different chemical environments, while the reaction sequence is using mild conditions and moreover can be synthesized in an one-pot procedure. The molecular structures were revealed by nuclear magnetic resonance spectroscopy and $x$-ray crystallography. The stability of the bisphosphorylimides against hydrolysis and thermal influences was tested which allows an initial estimation about the usage as flame retardant.

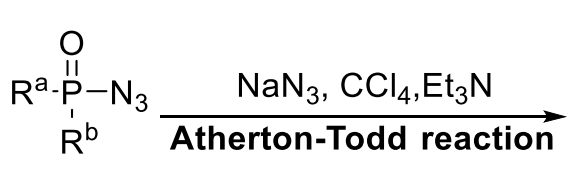

$\underset{\mathrm{R}^{\mathrm{b}}}{\stackrel{\mathrm{O}}{\mathrm{II}}-\mathrm{N}_{3}} \frac{\mathrm{NaN}_{3}, \mathrm{CCl}_{4}, \mathrm{Et}_{3} \mathrm{~N}}{\text { Atherton-Todd reaction }}$

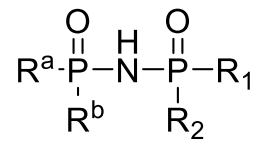

Keywords: 9,10-Dihydro-9-oxa-10-phosphaphenanthrene-10-oxide, phosphorus, bisphosphorylimides, Staudinger reaction, Atherton-Todd reaction 


\section{Introduction}

Bisphosphorylimides are organophosphorus compounds with a general structural unit $\mathrm{R}_{2} \mathrm{P}(\mathrm{O})-\mathrm{NH}-(\mathrm{O}) \mathrm{PR}_{2}$. Due to the biological activity phosphorus-nitrogen compounds are used as catalysts ${ }^{1}$ while playing a decisive role as a ligand. ${ }^{2-6}$

In recent years, the usage as phosphorus-nitrogen based flame retardants gets more attention and due to its versatility and effectiveness, phosphorus is a promising element to replace the widespread halogenated flame retardants. ${ }^{7-11}$ Phosphorus based flame retardants have shown direct correlation between the point of attack during burning and the chemical structure surrounding the phosphorus species. The combination of phosphorus groups with different chemical environments within one compound is a promising approach for an efficient flame retardant mechanism in gas and condensed phase, especially for composite materials due to the need of efficiency in both phases. ${ }^{12-16}$

From a synthetic point of view, the Staudinger reaction could achieve a facile and fast routine to access nitrogen-containing compounds with phosphorus in different environments to enable the previous mentioned efficient mode of action in gas and condensed phase. ${ }^{17-23}$

Various azides including carbonyl, sulfonyl and phosphoryl azides have been employed in this reaction. ${ }^{18,20,24}$ These azides can be easily obtained from the corresponding chlorinated species. Also, Shi et al. described the direct azidation of phosphites under modified Atherton-Todd conditions in which the chlorides occur as intermediates. ${ }^{25}$ Riesel et al. combined the Atherton-Todd and the Staudinger reaction in a one-pot synthesis. ${ }^{21}$

Aside from phosphazenes the corresponding structural element P-N-P however is described less frequently in literature and synthesis of nitrogen bridged di-phosphorus compounds often contain either extensive procedures, bad atom efficiency or hazardous byproducts. ${ }^{26-29}$

We successfully show the accessibility of apparent pentavalent phosphorus compounds via Staudinger reaction, taking advantage of the prototropic tautomeric equilibrium of phosphinylidene to synthesize several new flame retardants with phosphorus in different environments.

\section{Results and Discussion}

The intended DOPO-based bisphosphorylimides were prepared as shown in Scheme 1A. DOPO- $\mathrm{N}_{3}$ was obtained of either by azidation of DOPO under Atherton-Todd conditions in $92 \%$ yield or by a metathesis reaction DOPO-Cl with $\mathrm{NaN}_{3}$ in $90 \%$ yield as yellow oil. Column chromatography with $\mathrm{EE} /$ hexane $(60: 40)$ on silica gel yielded the spectroscopically pure product as a colorless oil $\left(R_{f}=0.66\right)$. For consecutive reactions, filtration of the crude product over silica gel and further extraction with $\mathrm{NaHCO}_{3} / \mathrm{H}_{2} \mathrm{O}$ was sufficient.

Diphenyl phosphoryl azide (DPPA) based bisphosphorylimides were prepared by a one-step procedure starting with the azide followed directly by Staudinger reaction (Scheme 1B). 
A<smiles>[R]P([R])[R]</smiles>

$\underset{\substack{\text { II } \\ \mathrm{R}^{a}-\mathrm{P}_{1}^{\mathrm{b}}-\mathrm{N}_{3}}}{\mathrm{R}^{\mathrm{O}}}$

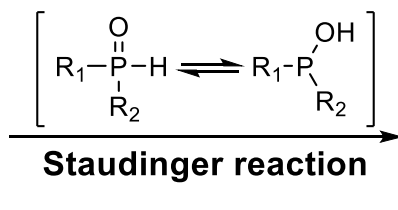

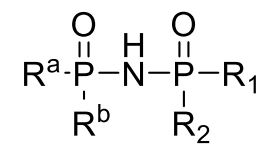
$\mathrm{R}^{\mathrm{b}}$

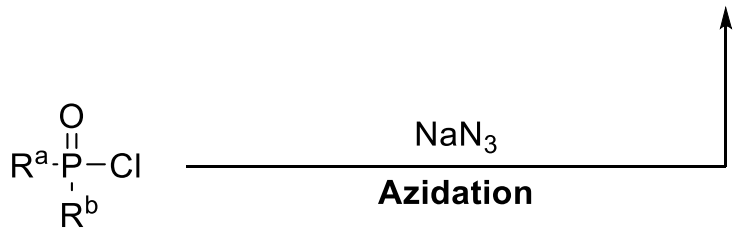

Scheme 1. General synthetic strategy of bisphosphorylimides via Atherton-Todd or direct Azidation followed by Staudinger reaction.

Compared to the Staudinger reaction procedure from trivalent phosphorus species (phosphanes and phosphites) the conversion of the apparent pentavalent species (diarylphosphine oxid, diarylphosphinate, dialkyl- and diarylphosphonate) needs more time and higher reaction temperatures. The complete conversion was achieved after five hours of reaction time at $80^{\circ} \mathrm{C}$ in acetonitrile. Scheme 2 is showing the synthesized DPPA- and DOPO- $\mathrm{N}_{3}$-based products.

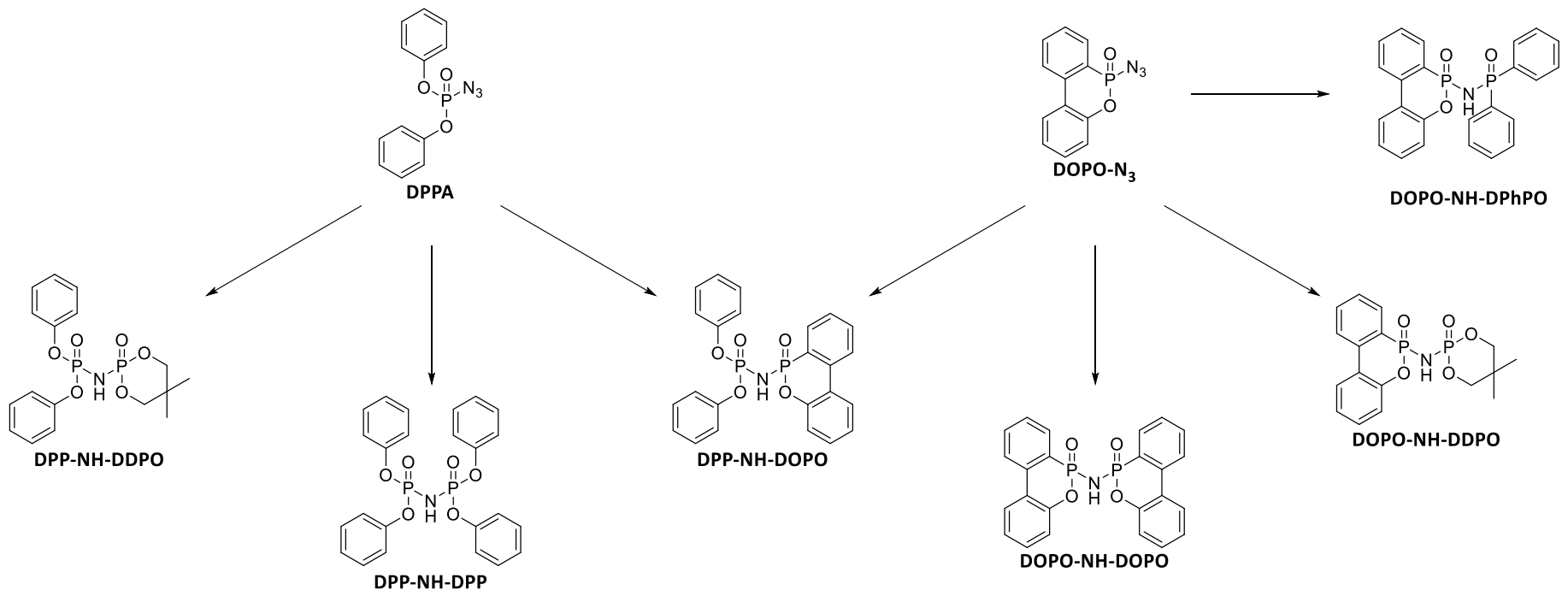

Scheme 2. Synthesis of DPPA- and DOPO-based bisphosphorylimides via Staudinger reaction.

For synthetic comparison and comparative analysis, the known reaction sequences from literature were studied and two examples are mentioned below. Nielsen has prepared bisphosphorylimides via condensation reaction from phosphorus chlorides and amines with sodium hydride. ${ }^{27}$ Wilkening et al. has researched peptide conjugation via Staudinger reaction, while preparing the trivalent phosphorus species using trimethylsilyl protecting groups. ${ }^{29}$

Also the conversion of sulfonyl azides was studied as shown in Scheme 3, starting with p-toluenesulfonyl chloride ( $p-\mathrm{TSS}-\mathrm{Cl}$ ) followed by azidation with $\mathrm{NaN}_{3}$ and Staudinger reaction similar to the previous described procedure of DPPA to form the desired imide salt. 


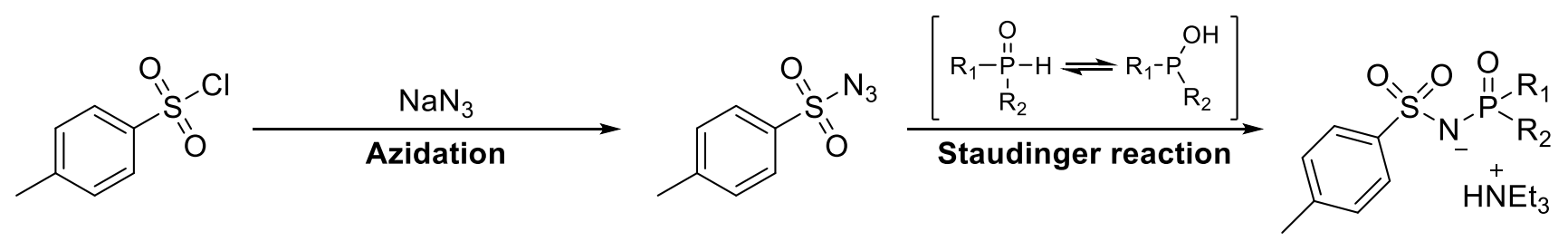

Scheme 3. Synthesis of p-toluenesulfonyl chloride-based bisphosphorylimides (pTSS-NH-DOPO) via Staudinger reaction.

The azidation without utilizing the Atherton-Todd reaction followed by Staudinger reaction was performed successively in a one-pot synthesis procedure, without any purification between the reaction steps. The conversion during the different procedures was confirmed using ${ }^{31} \mathrm{P}$ and ${ }^{1} \mathrm{H}-\mathrm{NMR}$. ${ }^{1} \mathrm{H}-\mathrm{NMR}$ spectra can show the characteristic signal pattern of DOPO or p-toluolsulfonyl species. ${ }^{31} \mathrm{P}-\mathrm{NMR}$ spectra indicate the ${ }^{2} \mathrm{JPP}_{\mathrm{PP}}$ coupling besides DPP-NH-DPP, which shows a singlet due to coincidence.

Crystal structure analysis. The bisphosphorylimides DOPO-NH-DOPO and DOPO-NH-DPhPO where recrystallized from isopropyl alcohol, whereas DPP-NH-DPP and DPP-NH-DOPO were recrystallized from chloroform to get single crystals useful for $\mathrm{x}$-ray diffraction analysis. Selected bonds and angles are summarized in Table 1. These data were discussed and compared among one another and additionally with a comparable crystalline structure from literature (Figure 1). Crystallographic data and structure refinement details are shown in the supplementary information.

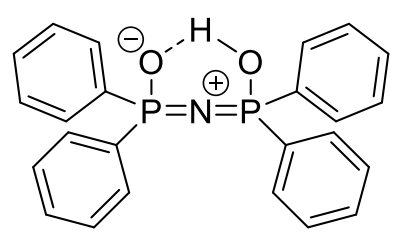

Figure 1. Comparable crystalline structure DPhPO-NH-DPhPO. ${ }^{30}$

Table 1. Summary of selected bond lengths in $\AA$ and bond angles in ${ }^{\circ}$ from synthesized products and selected reference compounds

\begin{tabular}{|c|c|c|c|c|c|c|}
\hline \multirow[t]{2}{*}{ Compounds } & \multicolumn{5}{|c|}{ Bond lengths $(\AA ̊)$} & \multirow{2}{*}{$\begin{array}{l}\text { Bond angles }\left({ }^{\circ}\right) \\
\text { P-N-P }\end{array}$} \\
\hline & P1-N1 & $\mathrm{P} 2-\mathrm{N} 1$ & $P 1=0$ & $P 2=0$ & N1---04/3 & \\
\hline DOPO-NH-DOPO & $1.646(0)$ & $1.658(8)$ & $1.457(1)$ & $1.473(1)$ & $2.795(7)$ & $130.5(8)$ \\
\hline DOPO-NH-DPhPO & $1.640(9)$ & $1.665(0)$ & $1.479(1)$ & $1.464(4)$ & $2.724(0)$ & 130.1(8) \\
\hline DPP-NH-DPP & $1.633(3)$ & $1.653(8)$ & $1.463(8)$ & $1.447(1)$ & $2.740(7)$ & 130.0(1) \\
\hline DPP-NH-DOPO & $1.649(5)$ & $1.637(0)$ & $1.470(7)$ & $1.459(9)$ & $2.731(7)$ & $132.5(4)$ \\
\hline DPhPO-NH-DPhPO ${ }^{30}$ & $1.535(1)$ & $1.535(1)$ & $1.519(2)$ & $1.519(2)$ & - & 180 \\
\hline
\end{tabular}

Staudinger reaction using the prototropic tautomeric equilibrium of phosphinylidene could lead to two different tautomeric products (Figure 2). To verify either structure, single-crystal X-ray analysis was used. The 
location of the hydrogen atom can be certainly identified at the nitrogen position, as seen in the crystal structure (Figure 3). Thereby the imide structure, rather than the phosphorylated iminophosphorane structure, can be verified for the synthesized di-phosphorus compounds.

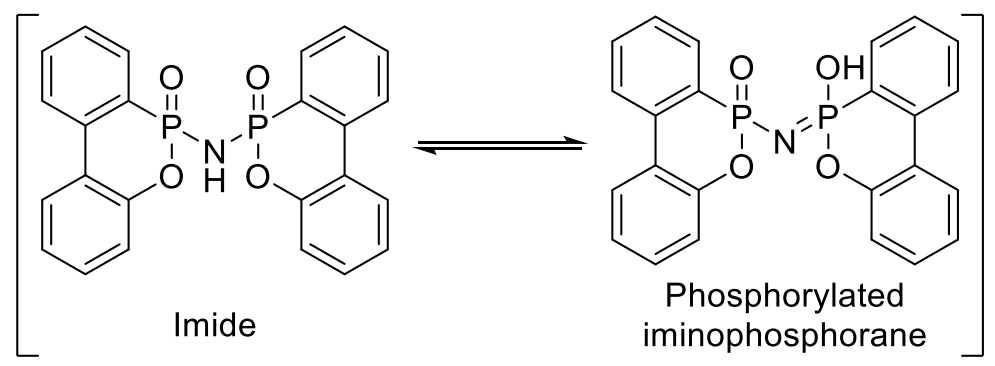

Figure 2. Possible structures resulting from DOPO-based Staudinger reaction.

The torsion angles of both ring elements in one DOPO-NH-DOPO are distinct from each other (P1 $19.03^{\circ}$ and $\mathrm{P} 2 \mathrm{11.59}^{\circ}$ ), therefore the structure does not contain a symmetric element. Remarkably is the syn conformation of both oxygen atoms $\mathrm{O} 2$ and 04 , which is caused by the intramolecular $\pi-\pi$-interaction. Both ring systems of the DOPO-NH-DOPO (Figure2) structure are aligned almost parallel (Angle $12.29^{\circ}$ ) with a distance of (3.64 \pm 0.29$) \AA$ between the rings.

The crystallographic data also show the existence of dimers of the above-mentioned single crystal structure of DOPO-NH-DOPO. Here, the oxygen atom 04 of each DOPO-NH-DOPO participates in an intermolecular hydrogen bond, while the oxygen atoms $\mathrm{O} 2$ remain free. Therefore, the lengths and angles of the bonds to $\mathrm{O} 2$ and 04 differ. The bond length P1-O2 with $1.4571 \AA$ is shorter than the length P2-O4, which is $1.4731 \AA$.

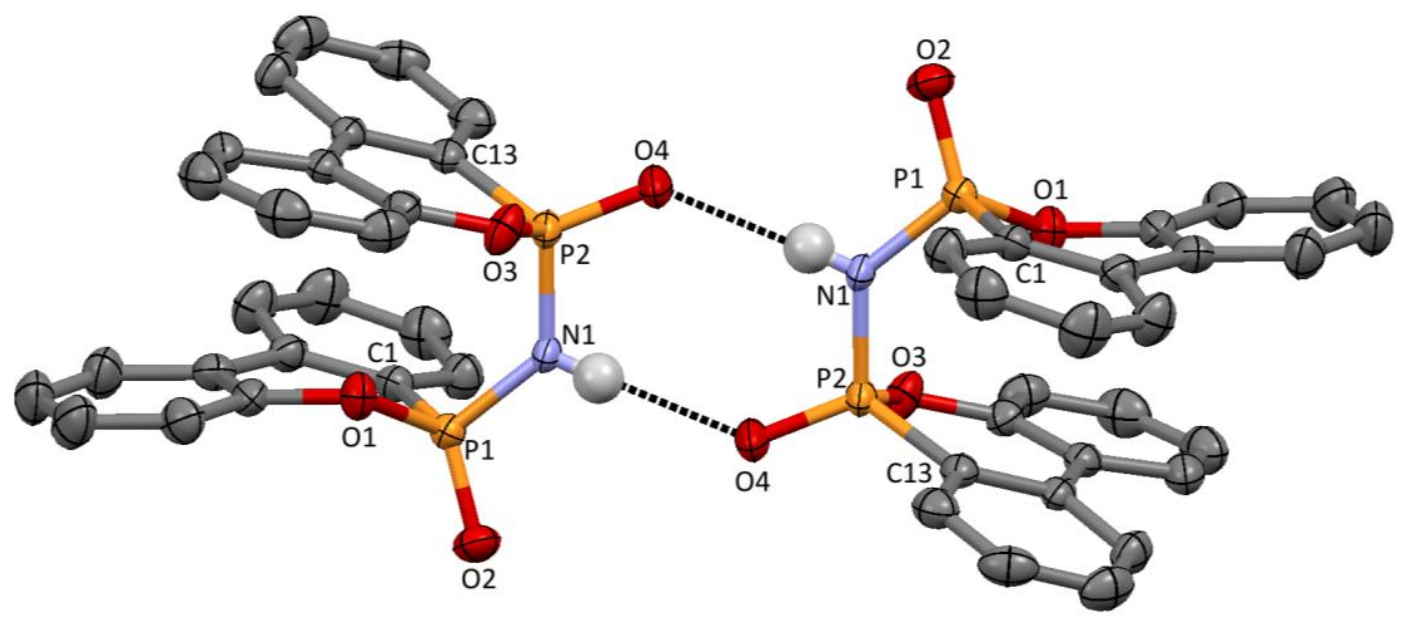

Figure 3. Dimeric molecular structure of DOPO-NH-DOPO. For clarity, $\mathrm{H}$-atoms of aromatic rings are omitted.

Besides DOPO-NH-DOPO, also DPP-NH-DOPO (Figure 4) shows the syn conformation of both oxygen atoms 02 and 05 . The oxygen atom $\mathrm{O} 2$ participates in the intermolecular hydrogen bond, whereas the oxygen 05 does not. The bond length P2-O5 with $1.4599 \AA$ is smaller than P1-O2 with $1.4707 \AA$.

In the crystal structure of DPP-NH-DOPO an almost parallel alignment (Angle $6.51^{\circ}$ ) of one aromatic ring (C13C18) with another aromatic ring of the DOPO unit with a distance of $(3.16 \pm 0.21) \AA$ can be observed. The distance between the interacting $\pi$-systems of both structures is in the expected range of shifted $\pi$-systems as 
benzene or nitrogen containing aromatic cycles (3.3-3.8 $)$ ), in which the second compound ranges on the bottom of the scale. ${ }^{31,32}$

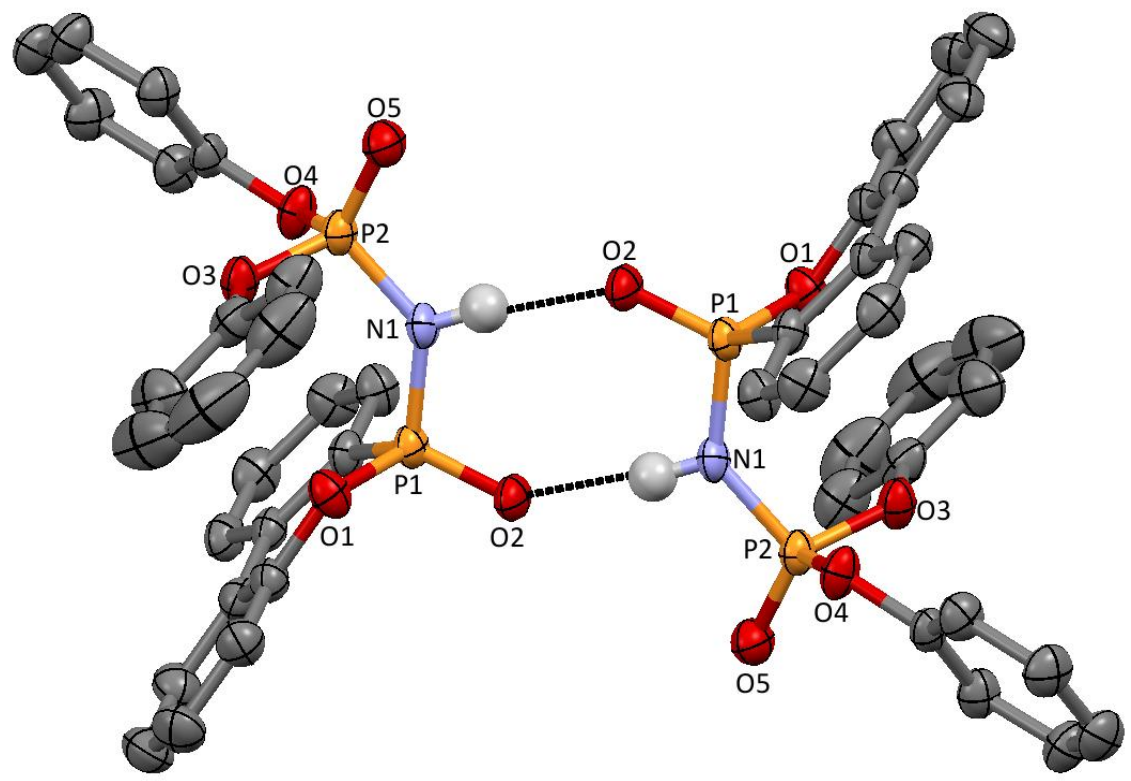

Figure 4. Dimeric molecular structure of DPP-NH-DOPO. For clarity, H-atoms of aromatic rings are omitted.

On the contrary, DOPO-DOPS-anhydride shows syn-conformation but no parallel alignment of the DOPO-units. In this case, sulfur acts as disruptive element and interferes with the orientation. The angle between the planes is $55.63^{\circ} .^{33}$ According to literature this syn-conformation could be observed before containing larger bridges between the interacting DOPO-units and can be verified for example for urea and hydroquinone bridged compounds. ${ }^{34,35}$ Urea-bridged DOPO is showing syn-conformation with an similar angle $\left(39.82^{\circ}\right)$ as DOPO-DOPS-anhydride and has a significant larger distance between the planes of $7.26 \pm 0.84 \AA$ as the new bisphosphorylimides. Hydroquinone-bridged DOPO structures display an angle of $10.98^{\circ}$ and a distance of $3.41 \pm 0.22 \AA$ and is with these values closer to bisphosphorylimides.

Usually the majority of structurally related compounds of the type $(R O){ }_{2} P(X)-N H-P(Y)\left(O R^{\prime}\right)_{2}$ with $X, Y=O, S$ and $\mathrm{R}, \mathrm{R}^{\prime}=\mathrm{Ph}, 2-\mathrm{Me}-\mathrm{Ph}, 3-\mathrm{Me}-\mathrm{Ph}, 4-\mathrm{Me}-\mathrm{Ph}$, as well as $\mathrm{Ph}_{2} \mathrm{P}(\mathrm{S})-\mathrm{NH}-\mathrm{P}(\mathrm{S}) \mathrm{Ph}_{2}$ are present in an anti-conformation. ${ }^{28}$ These anti conformations can be verified in the synthesized structures DPP-NH-DPP and DOPO-NH-DPhPO. In these structures, no intramolecular $\pi$-stacking was observed.

These structures also exist as a dimer connected with hydrogen bonds. The hydrogen located on the nitrogen and oxygen facing the same direction are participating in two hydrogen bonds and form the dimer. The lengths of the phosphorus and oxygen bonds in DPP-NH-DPP differ from $1.4638 \AA$ (P1-O3) within the hydrogen bond to $1.4471 \AA$ (P2-O6) between the not participating oxygen. Analog in the DOPO-NH-DPhPO structure, we can see the same difference in bond lengths. P1-O2 participates in the hydrogen bond with a length of $1.4791 \AA$ and is therefore longer than the corresponding P2-O3 bond with $1.4644 \AA$, which is not participating. 

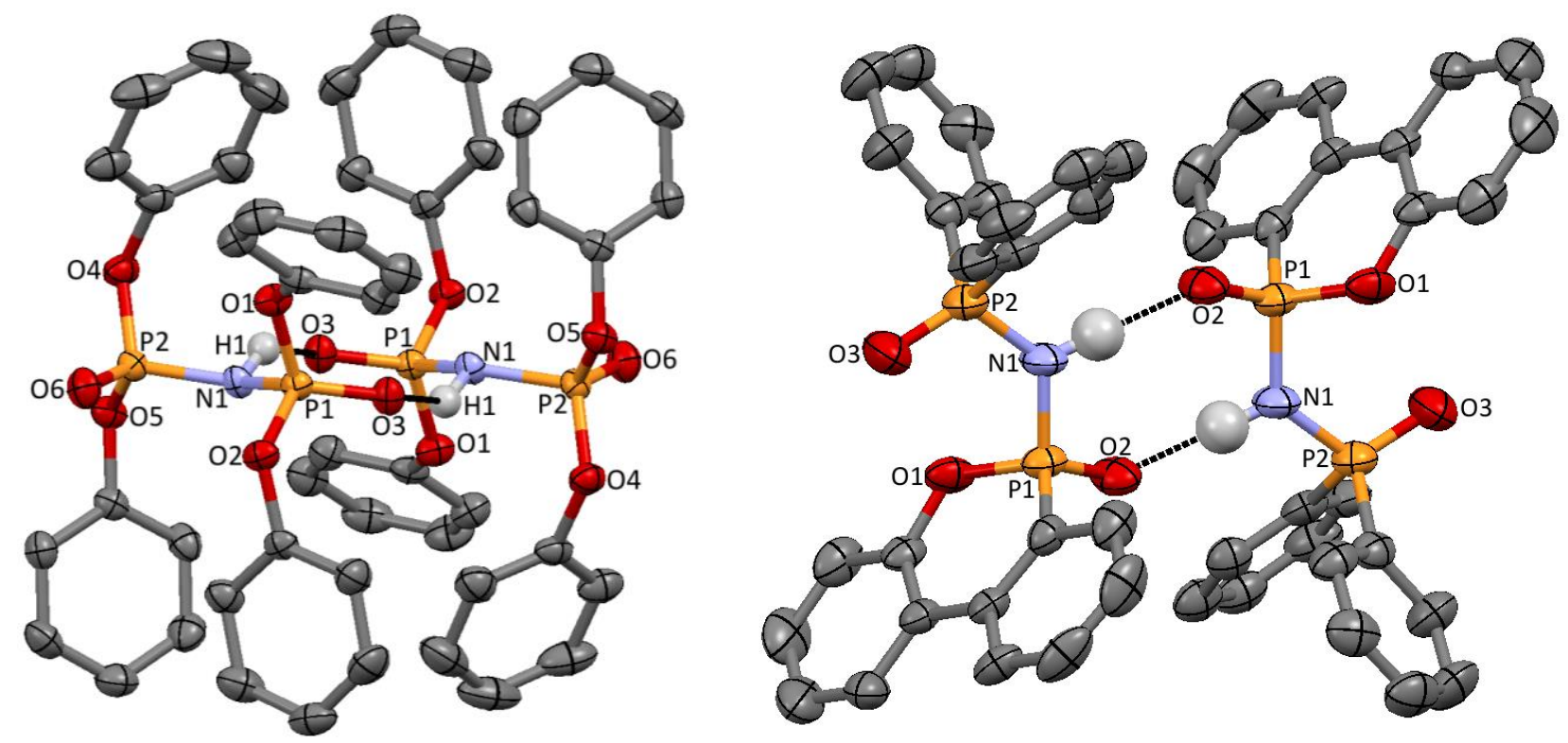

Figure 5. Dimeric structure of DPP-NH-DPP (left) and DOPO-NH-DPhPO (right).

These dimeric existences and different bond lengths are analogue to the characteristic crystal structures already described in literature. ${ }^{30,36}$

Regarding the bond lengths of the synthesized compounds and the structural data found in literature, a disparity can be observed. While the $\mathrm{P}-\mathrm{N}$-bond length in the new synthesized bisphosphorylimides are ranging around $1.648 \AA$, which is considered single-bond length, and are not showing much variation among the new molecules, the reference structure contains a bond with a length of $1.535 \AA$, which is regarded as a length of double-bonds. This difference in structure also applies to the P-N-P angles. ${ }^{37}$

Comparing the P-N-P angles of all the synthesized products are showing only small variations. The angles range around $130^{\circ}$ with a variation that does not exceed $1^{\circ}$. The angle of $130^{\circ}$ is distinct from the angle of the reference structure DPhPO-NH-DPhPO, with an angle of $180^{\circ}$. The difference between those structures is resulting from different hydrogen bond systems. Crystal structure analysis of DPhPO-NH-DPhPO confirmed a hydroxy phosphazene, as a polymeric chain with symmetric $\mathrm{O} \cdots \mathrm{H} \cdots \mathrm{O}$ hydrogen bonds resulting in an equidistant P-N bond length.

Behavior against hydrolysis. In organic and bioorganic chemistry, the products of the Staudinger reaction often undergo rapid hydrolysis delivering primary amines and phosphine (V) oxide. Staudinger products out of phosphor azides do not show the same lability. ${ }^{38}$

Thus the stability towards acidic hydrolysis of the synthesized product was tested in a simple NMR experiment exemplarily with two chosen compounds. DOPO-NH-DOPO and DPP-NH-DOPO were dissolved in acetonitrile/chloroform and treated with either water or $0.2 \mathrm{M}$ hydrochloric acid, each at room temperature or $50^{\circ} \mathrm{C}$ for two hours. During the treatment, no change in the 31P-NMR signals could be observed. These results are consistent with previous studies conducted with $\mathrm{N}$-phosphorylated iminophosphoranes as other Staudinger reaction products which are also stable against hydrolysis. ${ }^{18,38}$ The corresponding spectra are shown below. 


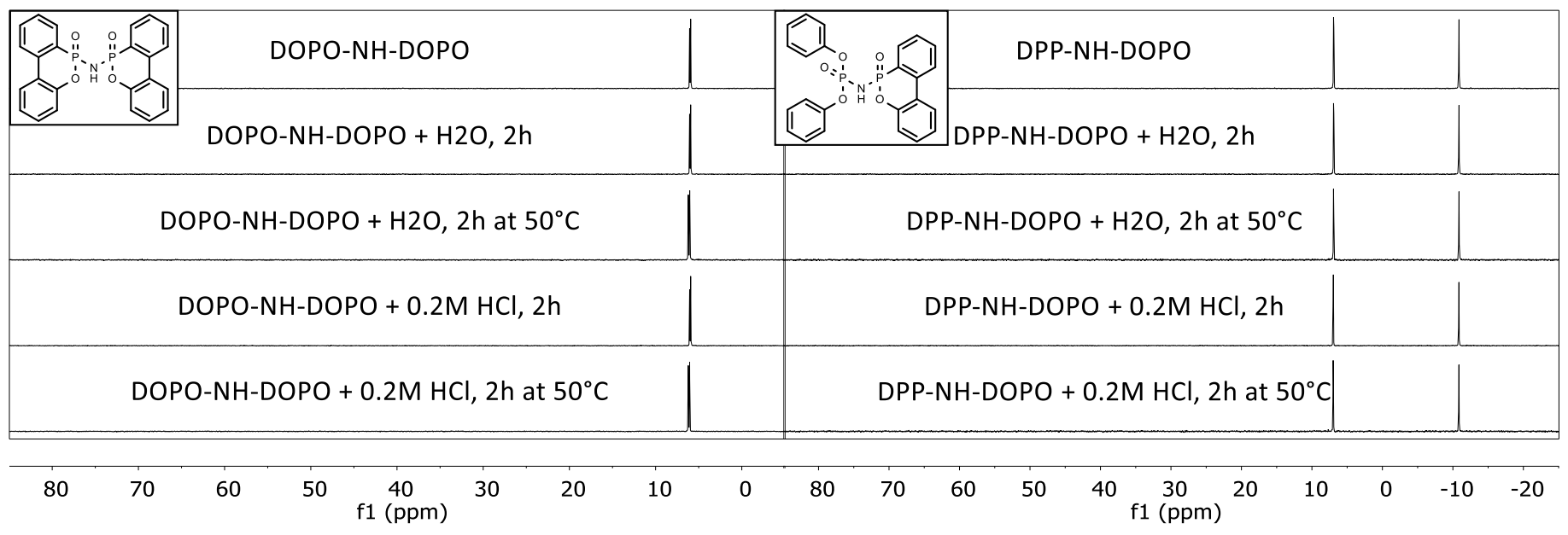

Figure 6. $31 \mathrm{P}\{1 \mathrm{H}\}-N M R$ spectra of DOPO-NH-DOPO and DPP-NH-DOPO during hydrolysis experiments recorded in a mixture of chloroform-d3 and Acetonitrile.

Thermal properties. To discuss and evaluate the possible application as flame retardant into either resin or thermoplastic polymer, the flame retardant must not decompose at temperatures below the resin's curing or compounding temperature. The thermal decomposition of the bisphosphorylimides was investigated using thermogravimetric analysis (TGA). The TGA curves of the novel flame retardants are displayed in Figure 7, compared to the known flame retardant phosphazene $\left[\mathrm{NP}(\mathrm{OPh})_{2}\right]_{\mathrm{x}}$.
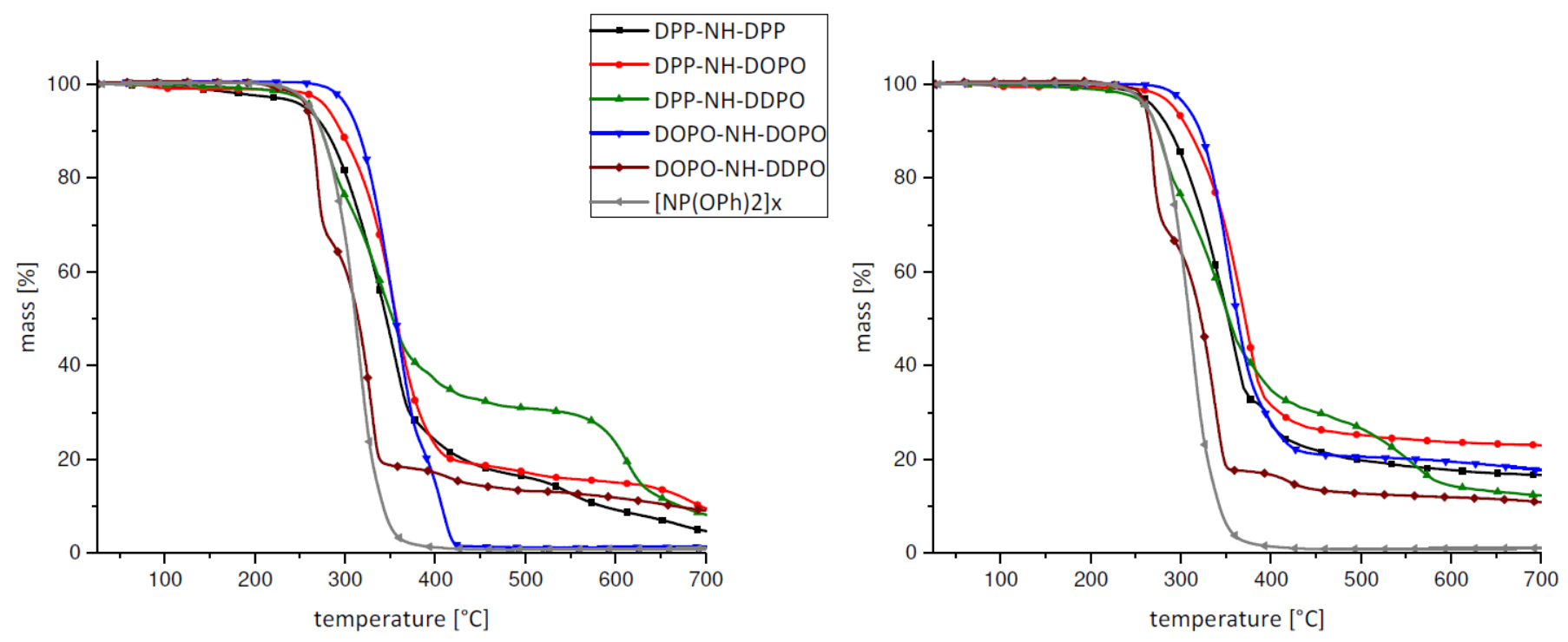

Figure 7. TGA curves of the new flame retardants under air (left) and nitrogen atmosphere (right).

DPP-NH-DPP is the least stable compound of this investigated array, starting to decompose before reaching $200^{\circ} \mathrm{C}$ under air and showing the biggest difference in decomposition temperature between air and nitrogen curves. In contrast, the curves of the other investigated compounds show less significant change. Based on hydrogen bridging and $\pi$-stacking stabilisation DOPO-NH-DOPO is the most stable of all investigated compounds, with a start of decomposition at $290^{\circ} \mathrm{C}$ (air) and $293^{\circ} \mathrm{C}$ (nitrogen). Also the thermal degradation of DOPO-NH-DOPO under air atmosphere is behaving similar to the reference substance $\left[\mathrm{NP}(\mathrm{OPh})_{2}\right]_{\mathrm{x}}$ while 
showing degradation at higher temperature. Both substances are showing little residue and therefore enter the gas phase almost exclusivly. In Table 2 decomposition temperatures at $2 \%$ weight loss $\left(T_{98}\right)$ as well as the temperatures corresponding to the maximum weight loss rate $\left(T_{\max }\right)$ and the residue at $700^{\circ} \mathrm{C}$ are listed.

Table 2. Thermal decomposition data of the additives based on TGA analysis recorded under nitrogen atmosphere and air

\begin{tabular}{|c|c|c|c|c|c|c|}
\hline \multirow[t]{2}{*}{ Compounds } & \multicolumn{3}{|c|}{ Air atmosphere } & \multicolumn{3}{|c|}{ Nitrogen atmosphere } \\
\hline & $\mathrm{T}_{98}\left[{ }^{\circ} \mathrm{C}\right]$ & $\mathrm{T}_{\max }\left[{ }^{\circ} \mathrm{C}\right]$ & $\begin{array}{c}\text { Residue }_{700^{\circ} \mathrm{C}} \\
{[\mathrm{wt} \%]}\end{array}$ & $\mathrm{T}_{98}\left[{ }^{\circ} \mathrm{C}\right]$ & $\mathrm{T}_{\max }\left[{ }^{\circ} \mathrm{C}\right]$ & $\begin{array}{c}\text { Residue }_{700^{\circ} \mathrm{C}} \\
{[\mathrm{wt} \%]}\end{array}$ \\
\hline DPP-NH-DPP & 181.7 & 354.0 & 4.8 & 252.7 & 354.0 & 16.6 \\
\hline DPP-NH-DDPO & 236.5 & 275.7 & 8.3 & 236.5 & 275.7 & 12.3 \\
\hline DPP-NH-DOPO & 260.0 & 354.0 & 9.6 & 275.7 & 369.7 & 23.0 \\
\hline DOPO-NH-DOPO & 290.4 & 353.4 & 1.4 & 292.3 & 354.5 & 17.7 \\
\hline DOPO-NH-DDPO & 244.6 & 269.1 & 9.1 & 254.7 & 321.4 & 10.9 \\
\hline$\left[\mathrm{NP}(\mathrm{OPh})_{2}\right]_{\mathrm{x}}$ & 246.9 & 313.5 & 1.0 & 248.0 & 310.7 & 1.1 \\
\hline
\end{tabular}

The results of DPP-NH-DDPO and DOPO-NH-DDPO display a two-step decomposition behavior with a more distinct second step in the curve of DPP-NH-DDPO. Both curves range around an initial decomposition temperature of $240^{\circ} \mathrm{C}$. These results indicate a close relationship between the chemical environment of the phosphorus and the thermal stability of the molecule. DOPO-containing compounds include P-C moieties and have a higher thermal stability than their counterparts not containing $\mathrm{P}-\mathrm{C}$ bonds. These results are consistent with the thermal degradation of triphenyl phosphate and triphenylphosphine oxide. ${ }^{39}$

TGA analyses in air atmosphere on compounds with phosphorus in different chemical environments result in more residue. The residue values of those compounds range from 8.3 to $9.6 \mathrm{wt} \%$, whereas the values for DPP-NH-DPP (4.8 wt\%) and DOPO-NH-DOPO (1.4 wt\%) as well as [NP(OPh) $]_{x}(1.0 \%)$ are significantly lower. Less residue indicate a ready transition into the gas phase, which is crucial for flame-retardants in order to perform an enhanced gas-phase activity. ${ }^{40}$ Considering the residue values for air and nitrogen a significant rise in weight can be observed for almost all compounds. DOPO-NH-DDPO and $\left[\mathrm{NP}(\mathrm{OPh})_{2}\right]_{\mathrm{x}}$ are the only compounds showing only a minor increase of weight $(1.0 \%$ and $0.1 \%)$ in nitrogen atmosphere.

\section{Conclusions}

Besides the previous researched Staudinger reaction as versatile tool in the synthesis of N-phosphorylated iminophosphoranes, ${ }^{24,38}$ the possibility converting apparent pentavalent phosphorus compounds using the prototropic tautomeric equilibrium was confirmed. This reaction pathway opens up a new and convenient synthesis-pathway of bisphosphorylimides, leading to a tunable array of molecules with different phosphorus moieties. This opens up an easy access to tailored phosphoryl imides, useful as flame retardants or ligands. 
Thus, five new bisphosphorylimides, with different chemical environments around the phosphorus, were synthesized using the Staudinger reaction. Moreover, the expected higher stability of the resulting products against hydrolysis was verified.

Single-crystal X-ray diffraction studies led to comparable results on molecular parameters and confirmed the bisphosphorylimides structure, rather than the iminophosphorane structure for the obtained products. In addition, the characteristic $\pi$-stacking of aromatic ring systems could be observed using the received parameters.

A relationship between the chemical environment around the phosphorus atom and the thermal stability of the corresponding compound was confirmed by TGA measurements. bisphosphorylimides with P-C moieties are thermally more stable than those with $\mathrm{P}-\mathrm{O}$ moieties.

\section{Experimental Section}

General. Unless stated otherwise, solvents and chemicals were obtained from Fisher scientific and used as received without further purification. DOPO was supplied by Metadynea Austria GmbH.

Diffraction data of a suitable crystal were collected on a STOE STADIVARI diffractometer. The crystal was kept at $180 \mathrm{~K}$ during data collection. Using Olex $2{ }^{41}$ the structure was solved with the ShelXT ${ }^{42}$ structure solution program using Intrinsic Phasing and refined with the ShelXL ${ }^{43}$ refinement package using Least Squares minimisation. Visualizations of crystal structures were created with Mercury 3.10 from Cambridge Crystallographic Data Centre (CCDC). ${ }^{44}$

The thermogravimetric analysis (TGA) of the flame retardant additives was performed with a METTLER TOLEDO TGA 1 STAR System in a nitrogen or air environment, keeping a gas flow of $30 \mathrm{~mL} \mathrm{~min}^{-1}$. The samples were heated starting from $25^{\circ} \mathrm{C}$ until $700^{\circ} \mathrm{C}$ with a rate of $10^{\circ} \mathrm{C}$ min- 1.

Nuclear magnetic resonance (NMR) data were obtained on a Bruker NanoBay 300 spectrometer. Chemical shifts are reported as $\delta$ values relative to the solvent peak in ppm. Trimethylsilane was used as a standard. For all ${ }^{31} \mathrm{P}-\mathrm{NMR}$ spectra proton decoupled and for ${ }^{1} \mathrm{H}-\mathrm{NMR}$ spectra phosphorus decoupled measurement was used.

FT-IR spectra were recorded with a Thermo Scientific ${ }^{\mathrm{TM}}$ Nicolet $^{\mathrm{TM}} 8700$ spectrometer (Diamond ATR cell). Evaluation of the spectra was carried out with Thermo Scientific ${ }^{\text {TM }}$ OMNIC ${ }^{\text {TM }}$ FTIR Software.

6-Azidodibenzo[c,e][1,2]oxaphosphinin-6-oxide (DOPO-N3). Synthesis is following the procedure according to literature. $^{38}$

Triethylammonium bis(6-oxidodibenzo[c,e][1,2]oxaphosphinin-6-yl)amide. DOPO (107.58 g, $497.65 \mathrm{mmol})$ and triethylamine $(50.36 \mathrm{~g}, 497.65 \mathrm{mmol})$ were dissolved under argon atmosphere in a three-necked round-bottom flask fitted with a condenser, $\mathrm{KPG}$ stirrer and septum in dry $\mathrm{CH}_{3} \mathrm{CN}$. Subsequently a solution of DOPO-azide (127.99 g, $497.65 \mathrm{mmol})$ in $\mathrm{CH}_{3} \mathrm{CN}$ was added dropwise at $70{ }^{\circ} \mathrm{C}$ and stirred until no more $\mathrm{N}_{2}$ evolved. The reaction mixture was concentrated and the product was filtered and washed with dioxane to yield the colorless solid product. 


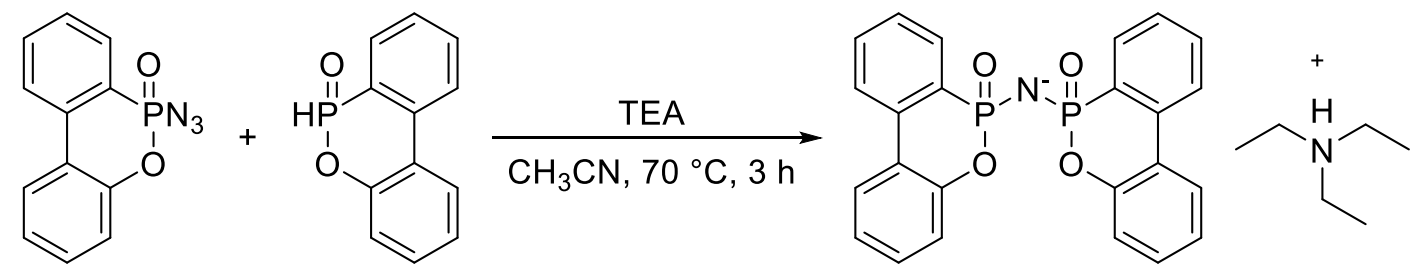

Yield: 71\%. ${ }^{31} \mathrm{P}-\mathrm{NMR}:\left(161.98 \mathrm{MHz}, \mathrm{DMSO}-d_{6}\right) \delta 2.19(\mathrm{~s}), 1.76(\mathrm{~s}) \mathrm{ppm} .{ }^{1} \mathrm{H}-\mathrm{NMR}:\left(400 \mathrm{MHz}, \mathrm{DMSO}-d_{6}\right) \delta 9.76(\mathrm{~s}$, 1H), 7.97 (dt, J.7.9, $2.1 \mathrm{~Hz}, 1 \mathrm{H}), 7.93(\mathrm{dt}, J 8.3,2.5 \mathrm{~Hz}, 1 \mathrm{H}), 7.73(\mathrm{dqd}, J 25.3,7.3,1.4 \mathrm{~Hz}, 1 \mathrm{H}), 7.53(\mathrm{t}, J 7.3 \mathrm{~Hz}$, 1H), $7.34(\mathrm{dt}, J 22.5,7.5 \mathrm{~Hz}, 3 \mathrm{H}), 7.16(\mathrm{tt}, J 7.5,1.3 \mathrm{~Hz}, 1 \mathrm{H}), 7.04$ (ddd, J 7.8, 6.1, $1.3 \mathrm{~Hz}, 1 \mathrm{H}), 2.88(\mathrm{q}, J 7.3 \mathrm{~Hz}$, $6 \mathrm{H}), 1.01(\mathrm{t}, J 7.3 \mathrm{~Hz}, 9 \mathrm{H}) \mathrm{ppm} .{ }^{13} \mathrm{C}-\mathrm{NMR}:\left(101 \mathrm{MHz}, \mathrm{DMSO}-d_{6}\right) 151.24(\mathrm{t}, J 3.0 \mathrm{~Hz}, 2 \mathrm{C}), 134.53(\mathrm{t}, J 3.1 \mathrm{~Hz}, 2 \mathrm{C})$, 132.41 (dt, J 174.1, 3.1 Hz, 2C), 130.21 (s, 2C), 129.33 (d, J $2.1 \mathrm{~Hz}, 2 \mathrm{C}), 128.57$ (t, J $4.8 \mathrm{~Hz}, 1 \mathrm{C}), 128.40$ (t, J $4.6 \mathrm{~Hz}, 1 \mathrm{C}), 127.23$ (td, J 7.2, $3.5 \mathrm{~Hz}, 2 \mathrm{C}), 125.03$ (d, J $2.2 \mathrm{~Hz}, 2 \mathrm{C}), 123.76$ (q, J $5.9 \mathrm{~Hz}, 2 \mathrm{C}), 123.40$ (td, J 5.2 , $2.6 \mathrm{~Hz}, 2 \mathrm{C}), 122.87$ (s, 2C), 120.02 (q, J $2.5 \mathrm{~Hz}, 2 \mathrm{C}), 45.28$ (s, 3C), 8.30 (s, 3C) ppm. MS calc. for $\left[\mathrm{C}_{24} \mathrm{H}_{17} \mathrm{NO}_{4} \mathrm{P}_{2}+\mathrm{H}\right]^{+} 446.0706$, found 446.0704 .

6,6'-azanediylbis(dibenzo[c,e][1,2]oxaphosphinine 6-oxide) (DOPO-NH-DOPO). Triethylammonium bis(6oxidodibenzo [c,e][1,2] oxaphosphinin-6-yl)amide (178.40 g, $326 \mathrm{mmol}$ ) was solved in chloroform and washed three times with $0.1 \mathrm{~N}$ aqueous hydrochloric acid and subsequently washed another three times with $\mathrm{H}_{2} \mathrm{O}$. The organic solution was concentrated in vacuo and the colorless product was filtered and washed with $\mathrm{H}_{2} \mathrm{O}$ before it was dried at $120^{\circ} \mathrm{C}$. Crystals were obtained after recrystallization from isopropanol.
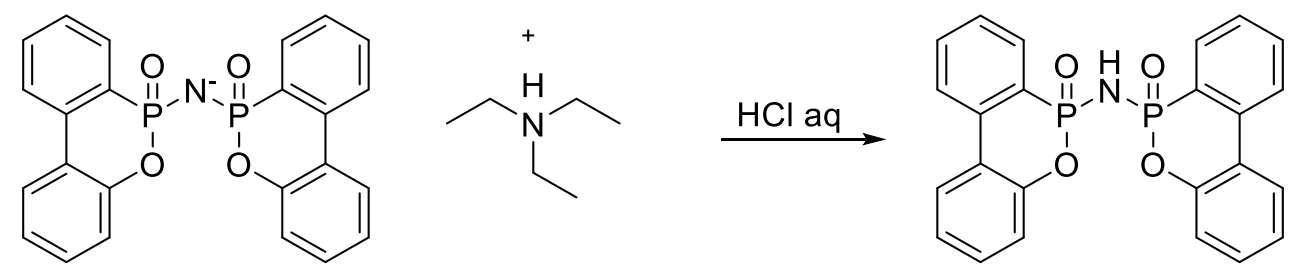

Yield: 99\%. ${ }^{31} \mathrm{P}-\mathrm{NMR}:\left(121.60 \mathrm{MHz}, \mathrm{CDCl}_{3}\right) \delta 5.90,5.70 \mathrm{ppm} .{ }^{1} \mathrm{H}-\mathrm{NMR}:\left(300.38 \mathrm{MHz}^{\mathrm{CDCl}} \mathrm{CD}_{3} \delta .32(\mathrm{~s}, 1 \mathrm{H}), 8.18-\right.$ $8.05(\mathrm{~m}, 4 \mathrm{H}), 7.90-7.67(\mathrm{~m}, 4 \mathrm{H}), 7.62-7.50(\mathrm{~m}, 2 \mathrm{H}), 7.44-7.37(\mathrm{~m}, 2 \mathrm{H}), 7.29-7.24(\mathrm{~m}, 2 \mathrm{H}), 7.17(\mathrm{dd}, \mathrm{J} 8.1$, $1.2 \mathrm{~Hz}, 1 \mathrm{H}), 7.10$ (dd, J 8.1, 1.2 Hz, 1H) ppm. ${ }^{13} \mathrm{C}-\mathrm{NMR}$ : (75.53 MHz, CDCl $)_{3} \delta 148.93(\mathrm{~d}, J 7.3 \mathrm{~Hz}, 1 \mathrm{C}), 148.84(\mathrm{~d}$, J $7.9 \mathrm{~Hz}, 1 \mathrm{C}), 135.07$ (d, J $7.3 \mathrm{~Hz}, 2 \mathrm{C}), 133.24-132.82(\mathrm{~m}, 2 \mathrm{C}), 130.41$ (d, J $2.9 \mathrm{~Hz}, 2 \mathrm{C}), 129.88$ (d, J $9.9 \mathrm{~Hz}, 1 \mathrm{C})$, $129.71(d, J 9.6 \mathrm{~Hz}, 1 \mathrm{C}), 128.38$ (d, J $14.8 \mathrm{~Hz}, 2 \mathrm{C}), 125.33$ (d, J $3.0 \mathrm{~Hz}, 2 \mathrm{C}), 124.92$ (d, J $164 \mathrm{~Hz}, 1 \mathrm{C}), 124.69$ (d, J $160.0 \mathrm{~Hz}, 1 \mathrm{C}), 124.53$ (d, J $3.8 \mathrm{~Hz}, 2 \mathrm{C}), 123.81(\mathrm{~d}, J 7.8 \mathrm{~Hz}, 1 \mathrm{C}), 123.75(\mathrm{~d}, J 11.6 \mathrm{~Hz}, 1 \mathrm{C}), 121.45(\mathrm{~d}, J 11.8 \mathrm{~Hz}$, 1C), 121.32 (d, J $11.9 \mathrm{~Hz}, 1 \mathrm{C}), 119.87$ (d, J $6.9 \mathrm{~Hz}, 2 \mathrm{C}) \mathrm{ppm} . \mathrm{IR}:(\mathrm{ATR}): \tilde{v}=3050\left(\mathrm{w}, \mathrm{C}_{\text {aryl }}-\mathrm{H}\right), 2947(\mathrm{w}, \mathrm{N}-\mathrm{H})$, 2700 (w, H-bridge), 1609 (w, $\left.\mathrm{C}_{\text {aryl }}=\mathrm{C}_{\text {aryl }}\right), 1597$ (w, $\left.\mathrm{C}_{\text {aryl }}=\mathrm{C}_{\text {aryl }}\right) 1585$ (w, $\left.\mathrm{C}_{\text {aryl }}=\mathrm{C}_{\text {aryl }}\right), 1561$ (w, $\left.\mathrm{C}_{\text {aryl }}=\mathrm{C}_{\text {aryl }}\right), 1478(\mathrm{~m}, \mathrm{~N}-$ H), 1448 (m, P-Caryl), $1431(\mathrm{~m}, \mathrm{P}=\mathrm{N}), 1352(\mathrm{~m}), 1257$ (s, P=O), 1207 (s), 1149 (s, P=O), 1121 (m, P-NH), 950 (vs, $\left.\mathrm{C}_{\text {aryl }}\right|^{-\mathrm{P}-\mathrm{O}),} 781$ (vs, $\mathrm{C}_{\text {aryl }}-\mathrm{H}$ ), 750 (vs, $\left.\mathrm{C}_{\text {ary }}\right|^{-\mathrm{H}} \mathrm{cm}^{-1}$. MS calc. for $\left[\mathrm{C}_{24} \mathrm{H}_{17} \mathrm{NO}_{4} \mathrm{P}_{2}+\mathrm{H}^{+} 446.0706\right.$, found [M+H] 446.0709. $\mathrm{TGA}: \mathrm{T}_{98}=290.4^{\circ} \mathrm{C}$ (air) $/ 292.3^{\circ} \mathrm{C}\left(\mathrm{N}_{2}\right)$. Smp.: $232.0^{\circ} \mathrm{C}$

\section{5,5-Dimethyl-1,3,2-dioxaphosphinane 2-oxide (DDPO)}

Synthesis is following the procedure according to literature. ${ }^{45}$ 
DDPO (10.29 g, $40 \mathrm{mmol})$ and triethylamine $(4.05 \mathrm{~g}, 40 \mathrm{mmol})$ were dissolved under argon atmosphere in dry $\mathrm{CH}_{3} \mathrm{CN}$. Subsequently, a solution of DOPO-azide $(10.29 \mathrm{~g}, 40 \mathrm{mmol})$ in dry $\mathrm{CH}_{3} \mathrm{CN}$ was added dropwise at $80^{\circ} \mathrm{C}$ and refluxed. After no more $\mathrm{N}_{2}$ evolved, the solvent was removed and the crude product was solved in chloroform to be treated with $0.1 \mathrm{M}$ aqueous hydrochloric acid. Then, the organic layer was washed with $\mathrm{H}_{2} \mathrm{O}$ three times before the solvent was removed.
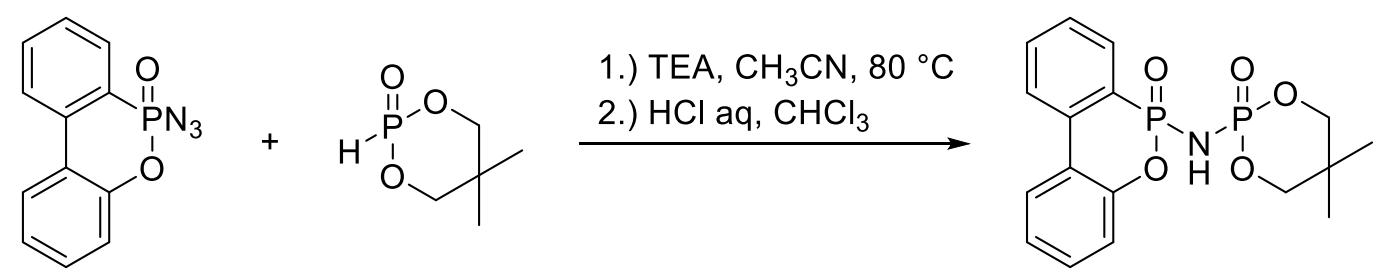

Yield: 56\%. ${ }^{31}$ P-NMR: (161.97 MHz, DMSO- $\left.d_{6}\right) \delta 7.35$ (d, J $\left.4.9 \mathrm{~Hz}\right),-7.96$ (d, J $\left.5.0 \mathrm{~Hz}\right)$ ppm. ${ }^{1} \mathrm{H}-\mathrm{NMR}:(400.13$ MHz, DMSO- $\left.d_{6}\right) \delta 8.29-8.17(\mathrm{~m}, 2 \mathrm{H}), 7.93(\mathrm{dd}, J 14.9,7.6 \mathrm{~Hz}, 1 \mathrm{H}), 7.79(\mathrm{t}, J 7.7 \mathrm{~Hz}, 1 \mathrm{H}), 7.63(\mathrm{td}, J 7.4,3.1 \mathrm{~Hz}$, $1 \mathrm{H}), 7.47(\mathrm{t}, J 7.7 \mathrm{~Hz}, 1 \mathrm{H}), 7.39-7.26(\mathrm{~m}, 2 \mathrm{H}), 4.21-4.13(\mathrm{~m}, 2 \mathrm{H}), 3.99-3.90(\mathrm{~m}, 2 \mathrm{H}), 1.05(\mathrm{~s}, 3 \mathrm{H}), 0.89(\mathrm{~s}, 3 \mathrm{H})$ ppm. ${ }^{13} \mathrm{C}-\mathrm{NMR}:\left(100.63 \mathrm{MHz}\right.$, DMSO- $\left.d_{6}\right) \delta 149.00(\mathrm{~d}, J 7.3 \mathrm{~Hz}, 1 \mathrm{C}), 135.21(\mathrm{~d}, J 7.0 \mathrm{~Hz}, 1 \mathrm{C}), 133.20$ (1C), 130.62 (1C), 129.76 (d, J $9.9 \mathrm{~Hz}, 1 C), 128.58$ (d, J $14.9 \mathrm{~Hz}, 1 \mathrm{C}), 125.55$ (1C), 125.16 (d, J $164.0 \mathrm{~Hz}, 1 \mathrm{C}), 124.72$ (1C), $123.99(\mathrm{~d}, J 11.3 \mathrm{~Hz}, 1 \mathrm{C}), 121.65$ (d, J $12.0 \mathrm{~Hz}, 1 \mathrm{C}), 120.13$ (d, J $6.7 \mathrm{~Hz}, 1 \mathrm{C}), 76.71$ (d, J $4.5 \mathrm{~Hz}, 1 \mathrm{C}), 31.67$ (d, J $6.1 \mathrm{~Hz}, 1 \mathrm{C}), 25.54(1 \mathrm{C}), 21.06$ (1C), 20.04 (1C) ppm. IR (ATR): $\tilde{v}=3050(\mathrm{w}), 1609(\mathrm{w}), 1597(\mathrm{w}), 1585(\mathrm{w})$, $1561(\mathrm{w}), 1478(\mathrm{~m}), 1448(\mathrm{~m}), 1431(\mathrm{~m}), 1352(\mathrm{~m}), 1257(\mathrm{~s}), 1243(\mathrm{~s}), 1225(\mathrm{~s}), 1207(\mathrm{~s}), 1149(\mathrm{~m}), 1121(\mathrm{~m})$, 1085 (w), 1044 (w), 967 (s), 950 (vs), 928 (s), 827 (m), 781 (s), 750 (vs), 712 (s) cm ${ }^{-1}$. MS calc. for [C ${ }_{17} \mathrm{H}_{19} \mathrm{NO}_{5} \mathrm{P}_{2^{-}}$ $\mathrm{H}]^{-} 378.0666$, found $378.0665[\mathrm{M}+\mathrm{H}]^{+}$. TGA: $\mathrm{T}_{98}=244.6^{\circ} \mathrm{C}$ (air) $/ 254.7^{\circ} \mathrm{C}\left(\mathrm{N}_{2}\right) . \mathrm{Smp} .: 248.6^{\circ} \mathrm{C}$.

$\boldsymbol{N}$-(6-Oxidodibenzo[c,e][1,2]oxaphosphinin-6-yl)-P,P-diphenylphosphinic amide (DOPO-NH-DPhPO). In a three-necked round-bottom flask fitted with a condenser, KPG stirrer and septum. Diphenylphosphine oxide (DPhPO) $(10.29 \mathrm{~g}, 40 \mathrm{mmol})$ and triethylamine $(4.05 \mathrm{~g}, 40 \mathrm{mmol})$ were dissolved under argon atmosphere in dry $\mathrm{CH}_{3} \mathrm{CN}$. Subsequently, a solution of DOPO-azide $(10.29 \mathrm{~g}, 40 \mathrm{mmol})$ in dry $\mathrm{CH}_{3} \mathrm{CN}$ was added dropwise at $80^{\circ} \mathrm{C}$ and refluxed. After no more $\mathrm{N}_{2}$ evolved, the solvent was removed and the crude product was solved in chloroform to be treated with $0.1 \mathrm{M}$ aqueous hydrochloric acid. Then, the organic layer was washed with $\mathrm{H}_{2} \mathrm{O}$ three times before the solvent was removed.
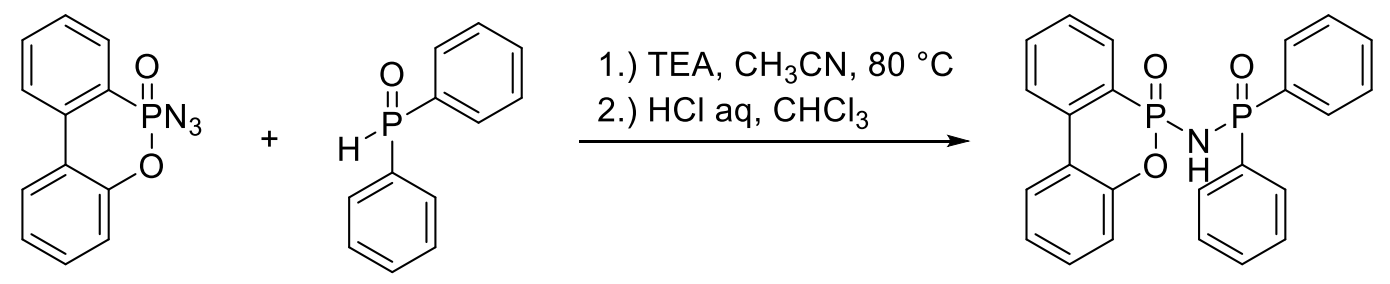

Yield: $<5 \%$

Because of the low yield further analytics could not be realized. Only some crystals could be obtained from the reaction mixture.

Tetraphenyl iminodiphosphate (DPP-NH-DPP). In a three-necked round-bottom flask fitted with a condenser and septum DPPA $(5 \mathrm{~g}, 18.17 \mathrm{mmol})$ and DPPH $(4.25 \mathrm{~g}, 18.17 \mathrm{mmol})$ were dissolved under nitrogen atmosphere in dry $\mathrm{CH}_{3} \mathrm{CN}$. Subsequently, triethylamin $(1.84 \mathrm{~g}, 18.17 \mathrm{mmol})$ was added dropwise at $80{ }^{\circ} \mathrm{C}$ and 
refluxed. After no more $\mathrm{N}_{2}$ evolved, the solvent was removed and the crude product was solved in $75 \mathrm{~mL}$ chloroform to be treated with $150 \mathrm{~mL} 0.1 \mathrm{M}$ aqueous hydrochloric acid. Then, the organic layer was washed five times with $\mathrm{H}_{2} \mathrm{O}$ before the solvent was removed. The pure colorless product was recrystallized as colorless solid from chloroform/n-hexan.

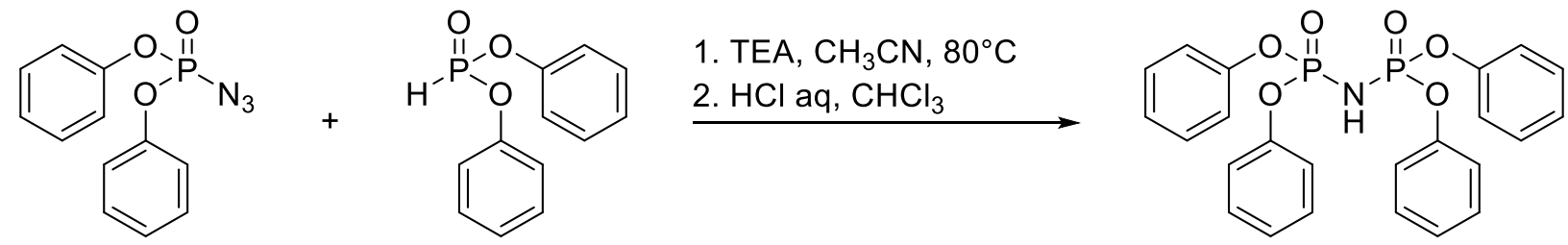

Yield: $82 \% .{ }^{31} \mathrm{P}-\mathrm{NMR}: \quad(121.60, \mathrm{CDCl}): \delta-10.85$ (s) ppm. ${ }^{1} \mathrm{H}-\mathrm{NMR}: \quad(300.38 \mathrm{MHz}, \mathrm{CDCl} 3): \delta 7,3-7,1(\mathrm{~m}$, $20 \mathrm{H})$ ppm. ${ }^{13} \mathrm{C}-\mathrm{NMR}:\left(75.54 \mathrm{MHz}, \mathrm{CDCl}_{3}\right): \delta 150.30(\mathrm{t}, \mathrm{J} 3.6 \mathrm{~Hz}, 4 \mathrm{C}), 129.65(\mathrm{~s}, 8 \mathrm{C}), 125.33(\mathrm{~s}, 4 \mathrm{C}), 120.54(\mathrm{t}, \mathrm{J}$ $2.4 \mathrm{~Hz}, 8 \mathrm{C})$ ppm. IR (ATR): $3059\left(\mathrm{w}, \mathrm{C}_{\text {aryl }}-\mathrm{H}\right), 2966$ (w, $\left.\mathrm{C}_{\text {aryl }}-\mathrm{H}\right), 2760$ (w, H-bridge), $1588\left(\mathrm{w}, \mathrm{C}_{\text {aryl }}=\mathrm{C}_{\text {aryl }}\right), 1483(\mathrm{~m}$, $\mathrm{N}-\mathrm{H}), 1404$ (m, P-Caryl), 1296 (m, P=O), 1242 (m, P=O), 1185 (s, P-N-H), 1155 (s, P-N-H), 1007 (m), 961 (m), 946 , 911, 840, 774, 753, $689\left(\mathrm{~s}, \mathrm{C}_{\text {aryl }}-\mathrm{H}\right) \mathrm{cm}^{-1}$. MS calc. for $\left[\mathrm{C}_{24} \mathrm{H}_{21} \mathrm{NO}_{6} \mathrm{P}_{2}-\mathrm{H}\right] 482.09$, found $482.09[\mathrm{M}+\mathrm{H}]^{+}$ TGA: $\mathrm{T}_{98}=181.7^{\circ} \mathrm{C}$ (air) $/ 252.7^{\circ} \mathrm{C}\left(\mathrm{N}_{2}\right)$. Smp.: $94.1^{\circ} \mathrm{C}$.

Diphenyl (6-oxidodibenzo[c,e][1,2]oxaphosphinin-6-yl)phosphoramidate (DPP-NH-DOPO). In a three-necked round-bottom flask fitted with a condenser and septum DPPA (6.39 g, $23 \mathrm{mmol}$ ) and DOPO (5.02 g, $23 \mathrm{mmol})$ were dissolved under nitrogen atmosphere in dry $\mathrm{CH}_{3} \mathrm{CN}$. Then triethylamine $(2.35 \mathrm{~g}, 23 \mathrm{mmol})$ was added dropwise at $70{ }^{\circ} \mathrm{C}$ and the mixture was stirred until no more $\mathrm{N}_{2}$ evolved. Then, the solvent was removed and the crude product was obtained. It was solved in $75 \mathrm{~mL}$ chloroform to be treated with $150 \mathrm{~mL} 0.2 \mathrm{M}$ aqueous hydrochloric acid. The organic layer then was washed five times with $\mathrm{H}_{2} \mathrm{O}$ before the solvent was removed. The pure colorless product was recrystallized from isopropanol.

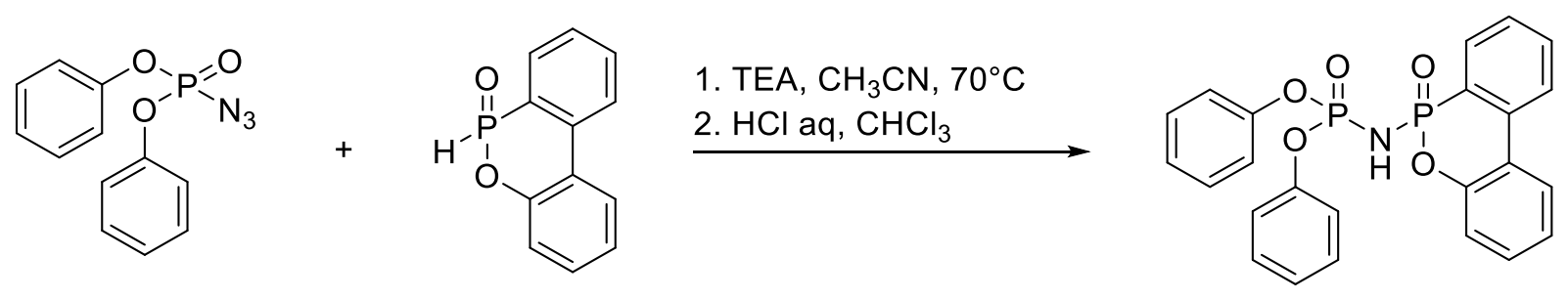

Yield: 95\%. ${ }^{31}$ P-NMR: (121.60, CDCl3) $\delta 2.87$ ppm (d, J $\left.44.2 \mathrm{~Hz}\right),-10.39$ ppm (d, J 44.2 Hz). ${ }^{1} \mathrm{H}-\mathrm{NMR}:(300.38$ $\mathrm{MHz}, \mathrm{CDCl} 3) \delta 7.99-7,91(\mathrm{~m}, 2 \mathrm{H}), 7.69-7.63(\mathrm{~m}, 2 \mathrm{H}), 7.35-7.11(\mathrm{~m}, 12 \mathrm{H}), 7.45(\mathrm{~m}, 1 \mathrm{H}) \mathrm{ppm} .{ }^{13} \mathrm{C}-\mathrm{NMR}:$ (75.54 MHz, CDCl 3 ): $\delta 150.23$ (d, J $3.8 \mathrm{~Hz}, 1 \mathrm{C}), 150.14$ (d, J 3.9Hz, 1C), 149.61 (d, J $7.5 \mathrm{~Hz}, 1 \mathrm{C}), 136.41(\mathrm{~d}, J$ $7.7 \mathrm{~Hz}, 1 \mathrm{C}), 133.13(\mathrm{~d}, J 2.5 \mathrm{~Hz}, 1 \mathrm{C}), 130.23(\mathrm{~d}, J 4.1 \mathrm{~Hz}, 1 \mathrm{C}), 129.62-129.55(\mathrm{~m}, 4 \mathrm{C}), 128.11(\mathrm{~d}, J 15.4 \mathrm{~Hz}, 1 \mathrm{C})$, 125.30-125.21 (m, 2C), 124.84-124.75 (m, 1C), 124.46 (d, J $4.9 \mathrm{~Hz}, 1 \mathrm{C}), 123.27$ (d, J $12.2 \mathrm{~Hz}, 1 \mathrm{C}), 121.42$ (d, J $12.1 \mathrm{~Hz}, 1 \mathrm{C}), 120.71$ (d, J $4.8 \mathrm{~Hz}, 2 \mathrm{C}), 120.57$ (d, J $4.9 \mathrm{~Hz}, 2 \mathrm{C}), 120.17$ (d, J $7.4 \mathrm{~Hz}, 1 \mathrm{C}) \mathrm{ppm}$. IR (ATR): $\tilde{v}=$

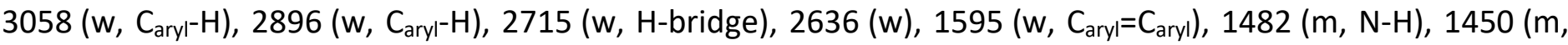
P-Caryl), $1383(\mathrm{~m}), 1274(\mathrm{~m}, \mathrm{P}=\mathrm{O}), 1215$ (m, P=O), 1186 (s, P-N-H), 1161 (s, P-N-H), 1120 (m, Caryl-O), 1006 (m, PO-C), 961 (vs, $\left.\mathrm{C}_{\text {aryl }}-\mathrm{P}-\mathrm{O}\right), 937,924\left(\mathrm{~s}, \mathrm{C}_{\text {aryl }}-\mathrm{H}\right), 897,845,791\left(\mathrm{w}, \mathrm{C}_{\text {aryll }}-\mathrm{H}\right), 751\left(\mathrm{vs}, \mathrm{C}_{\text {aryll }}-\mathrm{H}\right), 692\left(\mathrm{~m}, \mathrm{C}_{\text {aryl }}-\mathrm{H}\right) \mathrm{cm}^{-1}$. MS calc. for $\left[\mathrm{C}_{24} \mathrm{H}_{19} \mathrm{O}_{5} \mathrm{P}_{2} \mathrm{~N}_{1}-\mathrm{H}\right] 464.08$, found $464.08[\mathrm{M}+\mathrm{H}]^{+}$. TGA: $\mathrm{T}_{98}=260.0^{\circ} \mathrm{C}$ (air) $/ 275.7^{\circ} \mathrm{C}\left(\mathrm{N}_{2}\right)$. Smp.: $178.0^{\circ} \mathrm{C}$. 
Diphenyl (5,5-dimethyl-2-oxido-1,3,2-dioxaphosphinan-2-yl)phosphoramidate (DPP-NH-DDPO). In a threenecked round-bottom flask fitted with a condenser and septum DPPA (5 g, $18 \mathrm{mmol}$ ) and DDPO (2.73 g, $18 \mathrm{mmol}$ ) were dissolved under nitrogen atmosphere in dry $\mathrm{CH}_{3} \mathrm{CN}$. Then triethylamin $(1.83 \mathrm{~g}, 18 \mathrm{mmol})$ was added dropwise at $80^{\circ} \mathrm{C}$ and the mixture was stirred until no more $\mathrm{N}_{2}$ evolved. Then, the solvent was removed and the crude product was obtained. The crude product was solved in $75 \mathrm{~mL}$ chloroform to be treated with $150 \mathrm{~mL} 0.2 \mathrm{M}$ aqueous hydrochloric acid for $5 \mathrm{~h}$. The organic layer was washed five times with $\mathrm{H}_{2} \mathrm{O}$ before the solvent was removed. The pure product was obtained after crystallization from the received oil.

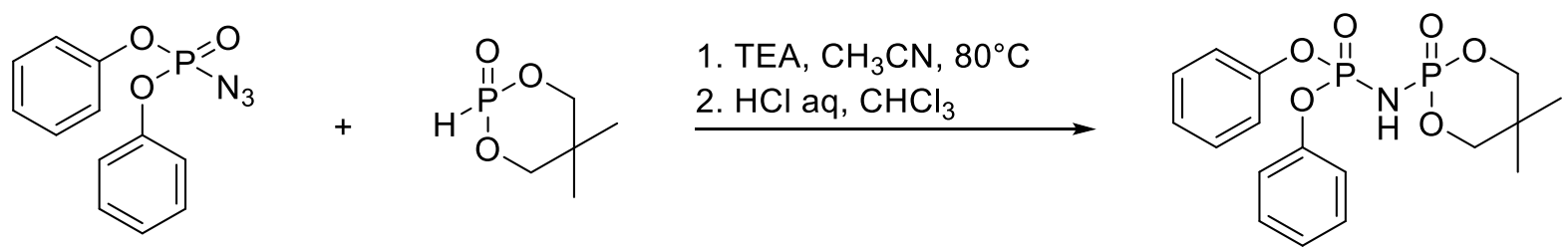

Yield: 21\%. ${ }^{31}$ P-NMR: $(121.60, \mathrm{CDCl} 3) \delta-8.28$ (d, $\left.1 \mathrm{P}, J 8.5 \mathrm{~Hz}\right),-8.62$ (d, $\left.1 \mathrm{P}, J 8.4 \mathrm{~Hz}\right) \mathrm{ppm} .{ }^{1} \mathrm{H}-\mathrm{NMR}:(300.38$ $\mathrm{MHz}, \mathrm{CDCl}$ ) $\delta$ 7.13-7.35 (m, 10H), 4.26 (d, J $10.8 \mathrm{~Hz}, 2 \mathrm{H}), 3.87$ (d, J $10.9 \mathrm{~Hz}, 2 \mathrm{H}), 1.16(\mathrm{~s}, 3 \mathrm{H}), 0.89$ (s, 3H) ppm. ${ }^{13} \mathrm{C}-\mathrm{NMR}:\left(75.54 \mathrm{MHz}, \mathrm{CDCl}_{3}\right) \delta 150.31(\mathrm{t}, \mathrm{J} 3.6 \mathrm{~Hz}, 2 \mathrm{C}), 129.64(\mathrm{~s}, 4 \mathrm{C}), 125.40(\mathrm{~s}, 2 \mathrm{C}), 120.78(\mathrm{t}, \mathrm{J} 2.4 \mathrm{~Hz}, 4 \mathrm{C})$, $77.71(\mathrm{~d}, J 6.5 \mathrm{~Hz}, 2 \mathrm{C}), 31.98$ (d, J $6.9 \mathrm{~Hz}, 1 \mathrm{C}), 21.89$ (s, 1C), $20.50(\mathrm{~s}, 1 \mathrm{C})$ ppm. IR (ATR): $\tilde{v}=2985(\mathrm{w}, \mathrm{C}$ aryl-H),

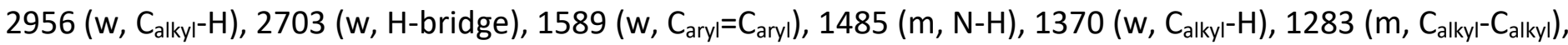
1263 (m, $\left.C_{\text {alkyl }}-C_{\text {alkyl }}\right), 1243$ (m, P=O), 1208 (m, P=O), 1183 (s, P-N-H), 1157 (s, P-N-H), 1067 (m, P-O-C), 1008 (s, $\mathrm{P}-\mathrm{O}-\mathrm{C}), 969,935,864,839,773,690\left(\mathrm{~s}, \mathrm{C}_{\text {aryl- }}-\mathrm{H}\right) \mathrm{cm}^{-1}$. MS calc. for $\left[\mathrm{C}_{17} \mathrm{H}_{21} \mathrm{O}_{6} \mathrm{P}_{2} \mathrm{~N}_{1}-\mathrm{H}\right]$ 398.09, found $398.09[\mathrm{M}+\mathrm{H}]^{+}$ TGA: $\mathrm{T}_{98}=236.5^{\circ} \mathrm{C} / 236.5^{\circ} \mathrm{C}\left(\mathrm{N}_{2}\right) . \mathrm{Smp} .: 131.9^{\circ} \mathrm{C}$.

\section{Supplementary Material}

Crystallographic data of DPP-NH-DPP, DPP-NH-DOPO, DOPO-NH-DOPO and DOPO-NH-DPhPO are shown in the supplementary information.

\section{References}

1. He, X.; Ji, Y.; Jin, Y.; Kan, S.; Xia, H.; Chen, J.; Liang, B.; Wu, H.; Guo, K.; Li, Z. J. Polym. Sci. Part A: Polym. Chem., 2014, 52, 1009-1019.

https://doi.org/10.1002/pola.27082

2. Lu, G.-Z.; Han, H.-B.; Li, Y.; Zheng, Y.-X. Dyes and Pigments 2017, 143, 33-41, https://doi.org/10.1016/j.dyepig.2017.04.016

3. Zhou, Y.-H.; Xu, J.; Wu, Z.-G.; Zheng, Y.-X. Journal of Organometallic Chemistry 2017, 848, 226-231, https://doi.org/10.1016/j.jorganchem.2017.07.039

4. Liu, N.; Wang, Y.; He, C.,Journal of Radioanalytical and Nuclear Chemistry 2016, 308, 393-401, https://doi.org/10.1007/s10967-015-4454-1

5. Tsoupras, A.B.; Roulia, M.; Ferentinos, E.; Stamatopoulos, I.; Demopoulos, C.A.; Kyritsis, P. Bioinorganic chemistry and applications. 
6. Wang, G.-C.; Sung, H.H.Y.; Dai, F.-R.; Chiu, W.-H.; Wong, W.-Y.; Williams, I.D.; Leung, W.-H., Inorganic chemistry 2013, 52, 2556-2563

https://doi.org/10.1021/ic302567e

7. Sun, Z.; Hou, Y.; Hu, Y.; Hu, W., Materials Chemistry and Physics, 2018, 214, 154-164. https://doi.org/10.1016/j.matchemphys.2018.04.065

8. Yang, S.; Hu, Y.; Zhang, Q., High Performance Polymers, 2019, 31, 186-196. https://doi.org/10.1177/0954008318756496

9. Li, Q.-L.; Huang, F.-Q.; Wei, Y.-J.; Wu, J.-Z.; Zhou, Z.; Liu, G. Materials Science 2018, 24, https://doi.org/10.5755/j01.ms.24.4.18606

10. Liu, X.; Liang, B., Materials Research Express 2017, 4, 125103. https://doi.org/10.1088/2053-1591/aa9dba

11. Kloock, C. Synthesis of Potential Phosphorus-Nitrogen Containing Flame Retardants. Honors Thesis, 2015.

12. Camino, G.; Luda, M.P.; Costa, L. Le Journal de Physique IV, 1993, 03, C7-1539-C7-1542.

https://doi.org/10.1051/ip4:19937240

13. Factor, A. Journal of Chemical Education, 1974, 51, 453. https://doi.org/10.1021/ed051p453

14. Lu, S.-Y.; Hamerton, I. Progress in Polymer Science 2002, 27, 1661-1712. https://doi.org/10.1016/S0079-6700(02)00018-7

15. Rakotomalala, M.; Wagner, S.; Döring, M. Materials (Basel, Switzerland), 2010, 3, 4300-4327. https://doi.org/10.3390/ma3084300

16. Wazarkar, K.; Kathalewar, M.; Sabnis, A. Polymer-Plastics Technology and Engineering 2016, 55, 71-91. https://doi.org/10.1080/03602559.2015.1038839

17. Staudinger, H.; Meyer, J. Helvetica Chimica Acta, 1919, 2, 635-646. https://doi.org/10.1002/hlca.19190020164

18. Baldwin, R.A.; Washburn, R.M. J. Am. Chem. Soc. 1961, 83, 4466-4467. https://doi.org/10.1021/ja01482a038

19. Gololobov, Y.G.; Zhmurova, I.N.; Kasukhin, L.F. Tetrahedron 1981, 37, 437-472. https://doi.org/10.1016/S004020(01)92417-2

20. Gololobov, Y.G.; Kasukhin, L.F. Tetrahedron 1992, 48, 1353-1406. https://doi.org/10.1016/S0040-4020(01)92229-X

21. Riesel, L.; Steinbach, J.; Herrmann, E. Z. Anorg. Allg. Chem. 1983, 502, 21-28. https://doi.org/10.1002/zaac.19835020704

22. Bräse, S.; Gil, C.; Knepper, K.; Zimmermann, V., Angewandte Chemie (International) 2005, 44, 5188-5240. https://doi.org/10.1002/anie.200400657

23. Köhn, M.; Breinbauer, R., Angew. Chem., 2004, 116, 3168-3178. https://doi.org/10.1002/ange.200401744.

24. Micle, A.; Miklášova, N.; Varga, R.A.; Pascariu, A.; Pleşu, N.; Petric, M.; Ilia, G. Tetrahedron Letters 2009, 50, 5622-5624.

https://doi.org/10.1016/j.tetlet.2009.07.112

25. Shi, E.; Pei, C., Synthesis 2005, 2005, 166.

https://doi.org/10.1055/s-2004-837286

26. Low, J.E. Investigation of Silicon- and/or Nitrogen-containing Phosphorus-based Compounds as Flame Retardants for Cotton Textiles, 2017.

27. Nielsen, M.L., Inorg. Chem. 1964, 3, 1760-1767. 
https://doi.org/10.1021/ic50022a024

28. Herrmann, E.; Nouaman, M.; Zak, Z.; Gromann, G.; Ohms, G. Z. Anorg. Allg. Chem. 1994, 620, 1879-1888, https://doi.org/10.1002/zaac.19946201108

29. Wilkening, I.; del Signore, G.; Hackenberger, C.P.R. Chem. Comm. 2011, 47, 349-351.

https://doi.org/10.1039/COCC02472D

30. Nöth, H., Zeitschrift für Naturforschung B 1982, 37, 1491-1498.

https://doi.org/10.1515/znb-1982-1201

31. Janiak, C., J. Chem. Soc., Dalton Trans. 2000, 3885-3896.

https://doi.org/10.1039/B0030100

32. Sinnokrot, M.O.; Valeev, E.F.; Sherrill, C.D. J. Am. Chem. Soc. 2002, 124, 10887-10893

https://doi.org/10.1021/ja025896h

33. Wagner, S.; Rakotomalala, M.; Bykov, Y.; Walter, O.; Döring, M. Heteroatom Chem. 2012, 23, $216-222$.

https://doi.org/10.1002/hc.21006

34. Burk, B. Entwicklung neuer Flammschutzmittel basierend auf Derivaten des 9,10-Dihydro-10oxaphosphaphenanthren-10-oxids; Verlag Dr. Hut: München, 2016.

35. Müller, P.; Bykov, Y.; Walter, O.; Döring, M. Heteroatom Chem. 2012, 23, 383-394, https://doi.org/10.1002/hc.21028

36. Kulpe, S.; Seidel, I.; Herrmann, E., Cryst. Res. Technol. 1984, 19, 661-668.

https://doi.org/10.1002/crat.2170190517

37. Bolboaca, M.; Stey, T.; Murso, A.; Stalke, D.; Kiefer, W. Applied spectroscopy 2003, 57, 970-976.

https://doi.org/10.1366/000370203322258931

38. Weinert, M.; Fuhr, O.; Döring, M. Arkivoc 2019, 278-293.

https://doi.org/10.24820/ark.5550190.p010.704

39. Horrocks, A.R.; Davies, P.J.; Kandola, B.K.; Alderson, A. Journal of Fire Sciences 2007, 25, 523-540. https://doi.org/10.1177/0734904107083553

40. Schartel, B., Materials (Basel, Switzerland) 2010, 3, 4710-4745.

https://doi.org/10.3390/ma3104710

41. Dolomanov, O.V.; Bourhis, L.J.; Gildea, R.J.; Howard, J.A.K.; Puschmann, H. J Appl Crystallogr. 2009, 42, 339-341.

https://doi.org/10.1107/s0021889808042726

42. Sheldrick, G.M. Acta crystallographica. Section A, Foundations and advances 2015, 71, 3-8.

https://doi.org/10.1107/S2053273314026370

43. Sheldrick, G.M. Acta crystallographica. Section C, Structural Chemistry 2015, 71, 3-8. https://doi.org/10.1107/S2053229614024218

44. Macrae, C.F.; Edgington, P.R.; McCabe, P.; Pidcock, E.; Shields, G.P.; Taylor, R.; Towler, M.; van de Streek, J. J Appl Crystallogr. 2006, 39, 453-457.

https://doi.org/10.1107/s002188980600731X

45. Oussadi, K.; Montembault, V.; Belbachir, M.; Fontaine, L., J. Appl. Polym. Sci. 2011, 122, 891-897.

https://doi.org/10.1002/app.34193.

This paper is an open access article distributed under the terms of the Creative Commons Attribution (CC BY) license (http://creativecommons.org/licenses/by/4.0/) 